\title{
YouTube-kanaal Tandartsassistent 2.0
}

Het kanaal Tandartsassistent 2.0 is een kanaal op de website YouTube die tandarts Berry Duizendstra en docent Elly Hogeveen hebben gevuld met beeldmateriaal dat voortvloeit uit een gezamenlijk geschreven (onderwijs) boek: Praktische vaardigheden voor tandartsassistenten. Tandartsassistent 2.0 brengt de vaardigheden en zelfstandige

(be) handelingen voor de tandartsassistent in beeld.

$\int$ e mbo-leerling is vaak op zoek naar beeldend materiaal bij de gegeven theorie. In het boek Tandheelkundige kennis voor tandartsassistenten dat Berry en Elly eerder schreven, zijn ze begonnen met het maken van een paar video's van praktische vaardigheden en die hebben ze - omdat ze het zo leuk vonden om te doen - uitgebreid met video's van zelfstandige (be)handelingen. Zodoende kwamen ze op het idee om een eigen YouTube-kanaal te beginnen waarop al deze video's gedeeld worden. Zo staan er filmpjes over: handschoen en wisselen, handhygiëne, lokale anesthesie, mengen, fluoride appliceren en matrixband aanbrengen.

Hun leerlingen waren zo blij met die eerste video's dat ze nog meer filmpjes hebben gemaakt. Deze komen allemaal op het YouTube-kanaal.

Berry is tandarts en Elly is van oorsprong preventieassistent. Ook is ze redacteur van Standby. Ze zijn collega-docenten aan de opleiding tot tandartsassistent op het ROC Friese Poort in Leeuwarden. Berry geeft de theoretische lessen en tandheelkundige kennis. Elly geeft de praktijklessen maar ook omgangskunde.

Los van elkaar hebben ze ieder een onderwijsboek geschreven. Berry schreef het theorieboek Tandheelkundige kennis voor tandartsassistenten en Elly samen met Standby-hoofdredacteur Maria de Vries, het boek Administratie voor tandartsassistenten. Ze zijn inmiddels in hun vrije tijd dit project aangegaan. Berry heeft haar tandheelkundige kennis ingevoegd en Elly haar praktijkervaring.

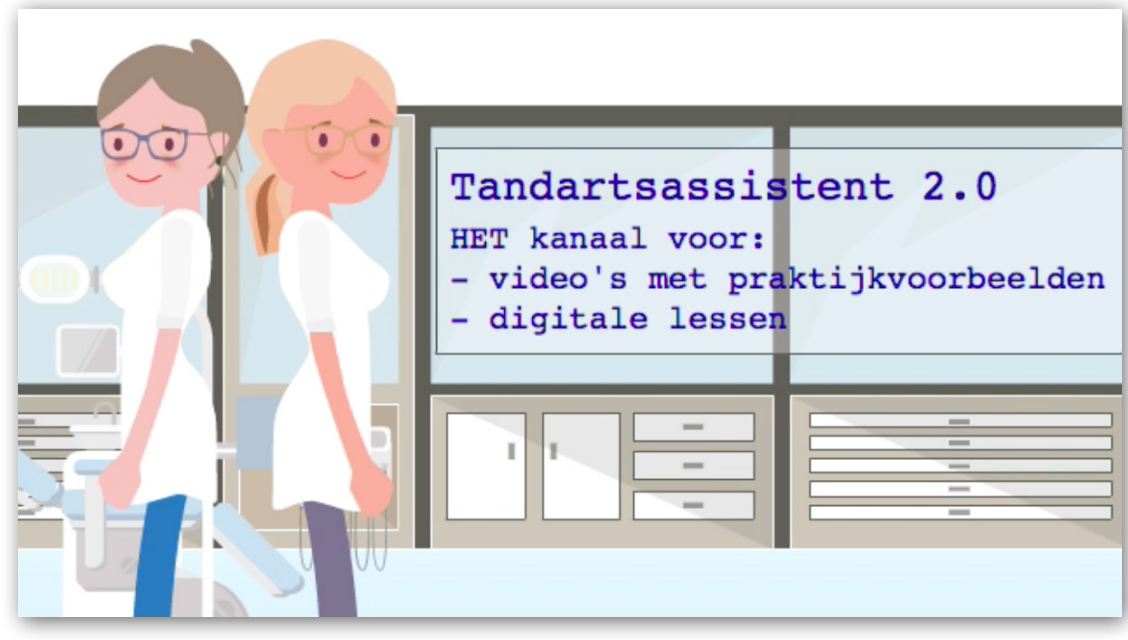

$\ldots \rightarrow$ Promotievideo YouTube-kanaal Tandartsassistent 2.0

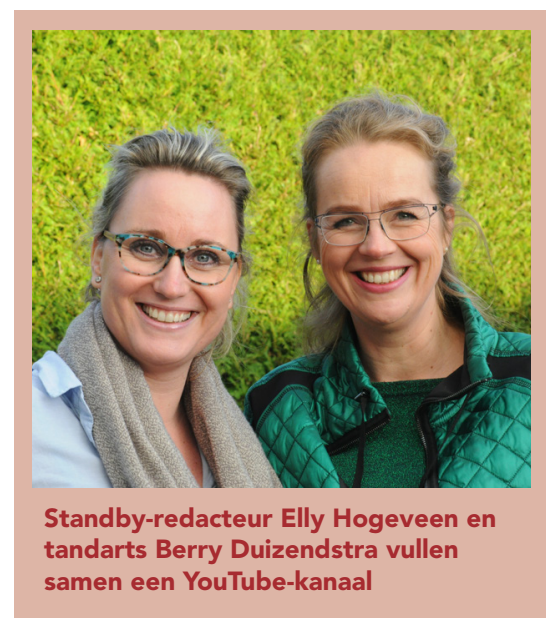

